
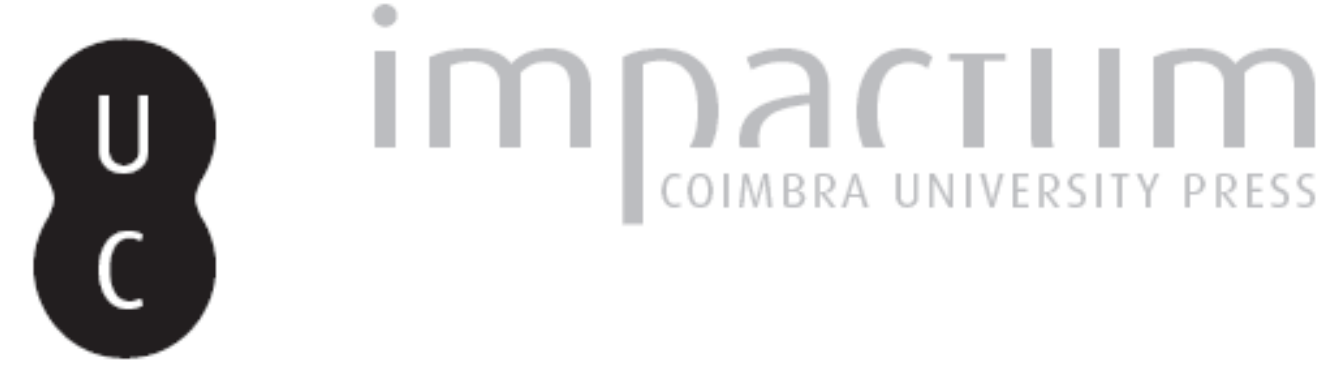

\title{
[Review] BARRIONUEVO, S, J. (2018). An overview of the Corpus Protagoreum: A Bibliographical Note on Laks and Most's Early Greek Philosophy
}
Autor(es):
Barrionuevo, Sergio Javier
Publicado por: Imprensa da Universidade de Coimbra; Annablume
URL persistente:
URI:http://hdl.handle.net/10316.2/43670
DOI:
DOI:https://doi.org/10.14195/1984-249X_23_11

Accessed : $\quad$ 26-Apr-2023 11:25:37

A navegação consulta e descarregamento dos títulos inseridos nas Bibliotecas Digitais UC Digitalis, UC Pombalina e UC Impactum, pressupõem a aceitação plena e sem reservas dos Termos e Condições de Uso destas Bibliotecas Digitais, disponíveis em https://digitalis.uc.pt/pt-pt/termos.

Conforme exposto nos referidos Termos e Condições de Uso, o descarregamento de títulos de acesso restrito requer uma licença válida de autorização devendo o utilizador aceder ao(s) documento(s) a partir de um endereço de IP da instituição detentora da supramencionada licença.

Ao utilizador é apenas permitido o descarregamento para uso pessoal, pelo que o emprego do(s) título(s) descarregado(s) para outro fim, designadamente comercial, carece de autorização do respetivo autor ou editor da obra.

Na medida em que todas as obras da UC Digitalis se encontram protegidas pelo Código do Direito de Autor e Direitos Conexos e demais legislação aplicável, toda a cópia, parcial ou total, deste documento, nos casos em que é legalmente admitida, deverá conter ou fazer-se acompanhar por este aviso.

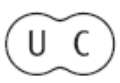




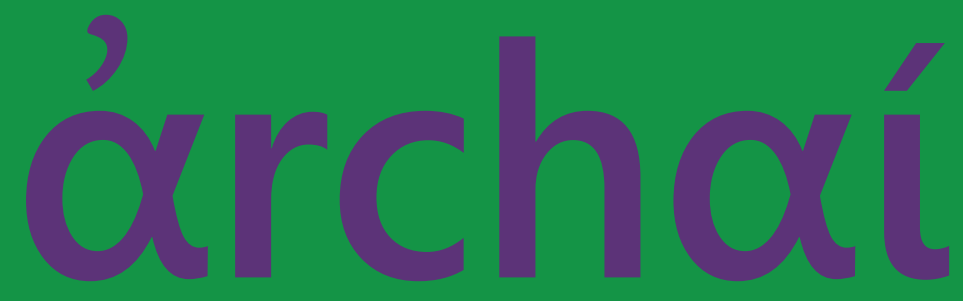

AS ORIGENS DO PENSAMENTO OCIDENTAL

THE ORIGINS OF WESTERN THOUGHT

May - Aug. 2018 


\section{AN OVERVIEW OF THE CORPUS Protagoreum: A Bibliograph- ICAL NOTE ON LAKS AND MOST'S Early Greek Philosophy}

BARRIONUEVO, S, J. (2018). An overview of the Corpus Protagoreum: A Bibliographical Note on Laks and Most's Early Greek Philosophy. Archai, n. ${ }^{\circ} 23$, May.-Aug., p. 343-374

DOI: https://doi.org/10.14195/1984-249X_23_11

\section{INTRODUCTION}

A new edition of Greek philosophical texts was recently published. The Loeb Classical Library edited by Harvard University Press was published in November 2016 and included the Early Greek Philosophy nine-volume work by André Laks and Glenn W. Most (2016a) [abbreviation: LM]. This edition was published simultaneously with the French version in one volume published by Fayard in Paris, titled Les Débuts de la Philosophie (Laks \& Most $2016 \mathrm{~b})$. The work establishes a new collection of

órchaí

no 23, May-Aug. 2018 


\section{o’rchaí}

no 23, May-Aug. 2018

Sergio Javier

Barrionuevo, 'An overview of the Corpus Protagoreum: A Bibliographical Note on Laks and Most's Early Greek Philosophy.', p. 343-374 writing fragments of the early Greek philosophers; it is described as an update to the canonical edition of Diels and Kranz (1952) [abbreviation: DK] and incorporates new historiographical and philosophical perspectives.

Laks and Most's edition requires a detailed analysis. For this reason, in this bibliographical note, I only propose a revision of the chapter dedicated to the sophist Protagoras from Abdera. First, I provide a historical overview of the construction of the Corpus Protagoreum. Then, I concentrate on the novelties presented by Laks and Most's new edition with respect to that of Diels and Kranz. Finally, I make some concluding remarks regarding this new collection.

\section{The edition of Protagoras' texts: An OVERVIEW}

Modern philological works have tended to constitute the literary corpus that brings together the conserved texts of ancient authors, which serves as a fundamental tool for historical work. The modern Corpus Sophisticorum has been established canonically from the edition of Herman Diels' Die Fragmente der Vorsokratiker, later enlarged and corrected by Walter Kranz. This corpus includes the Corpus Protagoreum as a "special corpus". In this case, since I am dealing with an author whose work is not preserved, but we know about it through testimonies and quotations from ancient authors, the corpus' conformation is of vital importance because it defines the universe from which the author would have given meaning to the world in which his work is inscribed. 
2.1. The EDition of Protagoras' fragments AND TESTIMONIES

At the beginning of the 19th century, Jacobi Geelin's Historia Critica Sophistarum Qui Socratis Aeatate Athenis Floruerunt (1823) presented the first "collection of fragments and testimonies" of Protagoras. As part of his attempt to reconstruct the life and work of the sophists from a work on the sources, Geel's work would serve as a basis for subsequent editions. However, the first edition of Protagoras' fragments and testimonies conceived as such was the one compiled by Ioannes Frei in Quaestiones Protagoreae (1845). Otto Weber's Quaestiones Protagoreae (1850), resulted from work on the commentaries of Aristotle and expands the collected texts, which were philosophically reorganized by Anne Joan Vitringa in Disquisitio of Protagorae Vita et Philosophia (1853). These books constitute the most significant contributions to the study of this sophist during the nineteenth century.

In 1903, at the dawn of the twentieth century, the German philologist Herman Diels published Die Fragmente der Vorsokratiker in 2 volumes, which constitutes the first corpus of philosophical fragments of authors prior to Socrates; this work includes as an annex a corpus of texts of the old sophistic. It was corrected and enlarged by his assistant Walter Kranz, whose definitive edition (1952) was considered canonical for the pre-Socratic fragments for a long time. ${ }^{1}$ Mario Untersteiner's 1949 book titled Sofisti: Testimonianze e Frammenti was primarily intended to bring Diels' work closer to the Italian students, but his

\section{o’rchoí}

no 23, May-Aug. 2018

Sergio

Javier

Barrionuevo,

'An overview of the Corpus Protagoreum: A Bibliographical Note on Laks and Most's Early Greek Philosophy.', p. 343-374 


\section{o’rchaí}

no 23, May-Aug. 2018
Sergio Javier

Barrionuevo, 'An overview of the Corpus Protagoreum: A Bibliographical Note on Laks and Most's Early Greek Philosophy.', p. 343-374 critical review of the fragments and the addition of texts not included in the canonical collection are a significant contribution to sophistical studies. Among the modifications introduced by Untersteiner, I will highlight the extension and updating of the critical apparatus of Diels, as well as the revaluation of the passage of De Melisso Xenophane Gorgia undervalued in the Diels' edition, introducing many amendments and defending new readings from the manuscripts. It also includes the anonymous De Lege and De Musica from the collection of sophistic texts, which was possibly influenced by Protagoras. In 1956, Antonio Capizzi published his book Protagora: le Testimonianze e Iframmenti, in which he made a critical review of Diels and Kranz (1952) as well as Untersteiner (1949). In this way, he includes about 50 new texts including testimonies and fragments, which, however, are recovered from the nineteenth-century editions (Geel 1823, Frei 1845, Weber 1850, and Vitringa 1853). ${ }^{2}$ Although new collections of the pre-Socratic texts have been published in the last decade, a new edition of the sophist texts has not been published for a long time. This puts them in a situation of delay with respect to the advances produced by paleographic works after Diels-Kranz and Untersteiner. For this reason, the work on Protagoras' fragments had to be complemented by the material included in Corpus Dei Papyri Filosofici (CPF) by Decleva Caizzi (1999: 663-676 $=C P F 88$ ) for a long time. Recently, Joel E. Mann (2012) has also published a critical edition of the Hippocratic treatise De $A r t e^{3}$ in which he defends the incorporation of this treatise as a sophistical text probably influenced by Protagoras. 
2.2. DEVELOPMENT IN THE COMPOSITION OF THE CORPUS Protagoreum: AN OVERVIEW

The historical development of the Corpus Protagoreum allows us to have an overview of some of the problems presented by its construction. First, we can observe a qualitative difference in the criteria of the collection and organization of texts. During the $19^{\text {th }}$ century, in the first collection sophist texts, Geel's edition organized the texts of Protagoras using four criteria: (1) vita et mortis, (2) placitis, (3) dicendi scribendique and genere and (3) dicendi ratione. In this book, Geel collects a considerable number of testimonies and quotations of Protagoras in a scholarly manner. Although many of the texts collected by him were subjected to critical revision by subsequent studies, his work on the sources was an unavoidable starting point in the constitution of the corpus. This work establishes the criteria from which the texts about Protagoras were organized in that century. However, Johann Frei's edition is considered as the first modern work dedicated exclusively to Protagoras. This study benefits from contributions made in previous works by Geist (1827) and Herbst (1832). In this book, Frei proposes a compilation, classification, and interpretation of the material around four aspects: (a) vita, (b) placita, (c) ars sophistica, and (d) scholis, discipulis, and scriptis. ${ }^{4}$ Although Otto Weber's book is based mainly on the works of Geel and Frei, the study of the commentaries on Aristotle allowed him to make significant contributions to these collections. This book is a product of his doctoral dissertation; for this reason, his objectives are much more restricted than those of Geel (1823)

\section{órchaí}

no 23, May-Aug. 2018

Sergio

Javier

Barrionuevo,

'An overview of the Corpus Protagoreum: A Bibliographical Note on Laks and Most's Early Greek Philosophy.', p. 343-374 


\section{o’rchaí}

no 23, May-Aug. 2018
Sergio Javier

Barrionuevo, 'An overview of the Corpus Protagoreum: A Bibliographical Note on Laks and Most's Early Greek Philosophy.', p. 343-374 or later, those of Vitringa (1853). Finally, the study of Vitringa (1853), based on critical work on the texts previously collected mainly by Geel (1823), Frei (1845), and Weber (1850), made a systematic work which organizes the texts in two parts: about Protagoras (Pars I) and his philosophy (Pars II). In the first part, he distinguishes between (1) vitae and (2) ingenio, moribus, and studiis; in the second, he distinguishes (1) de sensum perceptione, unico fonte cognitionis humanae, (2) de homine membro societatis humana, and (3) de disciplinis. He concludes with an epilogue on the sources of protagorean philosophy. In this book, he intends to carry out a philosophically systematic organization of the texts preserved on Protagoras. For this reason, his work is not only a critical review of the texts but also a proposal for a philosophical interpretation of its contents. Additionally, in the twentieth century, the collection by Diels (1903) plays a similar role as Geel's (1823). The classification of testimonies and fragments established by him endured for a long time during the twentieth century. Although the work was discussed and extensively revised, discussions focused on which texts to include in each section but not on the classification criteria. It was only at the end of the twentieth century that the criteria began to be reviewed in depth (see below $\$ 3.1$ ).

Furthermore, qualitative differences in the criteria allow quantitative differences to be established. Laks and Most's (2016) new edition presents a total of 108 texts. Most of the texts have already been edited by Diels and Kranz but are presented differently and organized or divided into several 
texts (see below \$3.2). Diels and Kranz’s edition collects a total of 46 texts for Protagoras, including testimonies (A: 30 texts), fragments (B: 12 texts), and imitations (B: 4 texts). However, in many cases, each text is composed by more than one source; they constitute a total of 63 passages. This work, in turn, critically reviews the previous collections (the nineteenth-century editions mainly), using modern philogical criteria to critically analyze and discard the different types of preserved texts, which modifies the quantity. A large part of the texts used in previous editions but eliminated by Diels and Kranz (1952) have been recovered in Capizzi’s (1956) edition.

\section{The NeW Edition by LAKs ANd Most (2016A)}

Among the change introduced by Laks and Most (2016) the most significant is the replacement of the category of "presocratics" with "early Greek philosophers", which allows them to include Socrates in this collection. This change in the collection criteria introduces a new long-term perspective to address the development of Greek thought. The grouping according to geographical criteria allows a greater understanding of its development, as well as the historical and thematic displacement of the first philosophers. This new edition also presents several differences with respect to the canonical edition of Diels and Kranz. The new criteria in the organization of the material lead them to multiply the number of texts listed; however, this also implies the exclusion of others. In this section, I will present the applied criteria and analyze some of the differences regarding the Diels and Kranz edition. ${ }^{5}$

\section{o’rchaí}

no 23, May-Aug. 2018

Sergio

Javier

Barrionuevo,

'An overview of the Corpus Protagoreum: A Bibliographical Note on Laks and Most's Early Greek Philosophy.', p. 343-374 


\section{o’rchaí}

no 23, May-Aug. 2018

\subsection{THE NEW CRITERIA}

The canonical edition of Diels and Kranz (1952) established the distinction between testimonies (A), fragments (B), and Imitations (C) as the criteria for the organization of texts. This criterion was maintained during the 20th century. Recently, the new edition of The Milesian School by G. Wöhrle (200911) included in the collection Traditio Praesocratica: Zeugnisse Fruhgriechischer Philosophie und Ihres Fortlebens has reviewed the criteria. Since this collection is intended to document the transmission of early Greek philosophers as preserved in the tradition of several classical philosophical schools and late antiquity, Diels and Kranz's criteria is insufficient. Wöhrle's edition, however, focuses on the reception of doctrines by tradition; although there are no Milesian fragments, the organization of the material presents no greater difficulty. The same happens with the edition of Heraclitus by Serge Mouraviev (19992011), who devotes several volumes to the tradition. ${ }^{6}$ To some extent, Laks and Most (2016) share some points with the edition of Mouraviev for Heraclitus. One of the constants in the renewal of studies about early philosophers is the importance given to the reception of philosophical texts, as can be seen in De Gruyter's new collection (Traditio Praesocratica: Wöhrle 2009-11) and in Mouraviev's (1999-2011) edition. This perspective is enriched mostly by the work around the history of reading practices. This perspective is mobilized from works carried out on the doxographic tradition (Osborne 1987), and received great impetus and renewal from the studies of cultural history around the history of reading practices (Svenbro 1988; Cavallo and Chartier, eds., 1997). 
The chapter dedicated to Protagoras, which is the general criterion for chapters dedicated to authors, is divided into Person (= P), which collects information about his person (physical or imagined) as well as about his life, character, or what is said about him; Doctrine $(=\mathrm{D})$ incorporates testimonies about his thought along with the preserved fragments; and Reception (= R), where the change is provided about how his doctrine was received in antiquity. This type of organization of the texts presents some advantages with respect to the classification of Diels and Kranz. It avoids the problem of discussing the inclusion of a text as a fragment or testimony, even though textual quotations are indicated in boldface typography. $D$ includes as many quotations as the testimonies about the statements attributed to them, while $R$ allows him to group not only its reception by the doxographic tradition but also its reception by authors who were to some extent contemporary. However, it allows solving the question around the Platonic tradition. This shows to what extent the Platonic testimony may or may not be considered a reproduction of sophistic thinking. The inclusion of many Platonic texts considered 'B' by Diels and Kranz (1952) in the category R by Laks and Most (2016a) allows them to solve the question of their inclusion in the Corpus Protagoreum. Although they cannot be affirmed as protagorean texts, they are considered later receptions of doctrines of this sophist and, therefore, as allusions to his thought.

\subsection{THE REDISTRIBUTION OF SOME TEXTS}

The increase in the number of texts that compose this new collection compared to that of Diels and

\section{o’rchaí}

$n^{\circ} 23$, May-Aug. 2018

Sergio

Javier

Barrionuevo,

overview of the

Corpus Protagoreum:

A Bibliographical

Note on Laks and Most's Early Greek Philosophy.', p. 343-374 


\section{o’rchaí}

no 23, May-Aug. 2018
Sergio Javier

Barrionuevo, 'An overview of the Corpus Protagoreum: A Bibliographical Note on Laks and Most's Early Greek Philosophy.', p. 343-374
Kranz (see above \$2.2) is due in large part to the redistribution of texts rather than the incorporation of new texts (see below \$3.3). Diels and Kranz included some texts as testimonies or fragments, while in the Laks and Most's edition, they are divided into several texts on the person of Protagoras (such as Athenaeus, V.218b = DK80A11, that is included as $\mathrm{P9a}, \mathrm{P9b}$ ), on its doctrine (this is the case of the testimonies of Stephanus of Bysantium, s.v. "A $\beta \delta \eta \rho \alpha$ $=$ DK80A21, included as D28, R18, and Plato, Cratylus 391b-c = DK80A24, separated in D5b, D21; as well as the fragment in Cicero, Brutus 12.46 and Quintilian, Training in Oratory 3.1.12 = DK80B6, divided into D18, D19respectly), or the reception of his thought (this happens with the testimonies of Sextus Empiricus, Against the Logicians 7.38990 = DK80A15, divided into R22, R9b; and Plato, Euthydemus 286b-c = DK80A19, separated as R10, R14a, R17; as well as with the fragment in Diogenes Laertius III.37 = DK80B5, included as R1a, R1b).

Other texts are not divided into such homogeneous parts but are divided into different sections. This is the case, for example, of the extensive testimony of Diogenes Laertius IX.50-56 (= DK80A1), from which twenty-one texts are derived (eleven in the 'Person' section: P1, P3, P5, P6a, P8, P12, P13b, P19, P20, P23; seven in the 'Doctrine' section: D1, D4a, D15, D17, D20, D26, D29; two in the 'Reception' section: R13, R19b; and one in chapter 43: "Philosophy and Philosophers in Greek Comedy and Tragedy": Dram T18b). Something similar happens with the testimony of Plato, Protagoras 317b-319a (= DK80A5), which is divided into eight texts (two in 'Person': P2a, P13a, three in 'Doctrine': D35, 
D36, D37, and three in chapter 42 "'Sophist' and 'Sophistic': Collective Representations and General Characterization": R11a, R11b, R12); with the testimony of Athenaeus V.218b (= DK80A11), divided into 5 texts (two in the 'Person' section: P9a, P9b; three in chapter 43: Dram T18a, T18b, T18c), and with the fragment in Sextus Empiricus, Against the Logicians VII.60 (= DK80B1), divided into 7 texts (three in the 'Doctrine' section: D3, D5a, D9; and four in 'Reception': R4, R5, R7a, R20). Other texts are divided into fewer categories, for example, the testimonies of Philostratus, Life of Sophists I.10.1-4 (= DK80A2), Hesychius, Onomatol. in Scholia of Plato, Republic 600c (= DK80A3), and Plato, Protagoras 339a (= DK80A25), which are divided into four texts each (the first is distributed in two for the 'Person' section: P7, P21 and two in 'Reception': R3, R25; the second is divided into 'Person': P6b, P13c, P16, and 'Doctrine': D16; while the third contains three texts corresponding to the chapter of "Protagoras [31]", one in 'Person': P18, two in 'Doctrine': D31, D42; and one in chapter 3 "Reflection on Gods and Men": Mor. T37). The fragment in Anecdota Graeca I.171.31 (= DK80B3) is also divided into four texts (three in the chapter on "Protagoras [31]": two in 'Doctrine': D8, D11, one in 'Reception': R23, and one in chapter 43: Dram. T71). The testimony of Sextus Empiricus, Against the Logicians IX.55-56 (= DK80A12) and the fragment in Porphyrius, Philological courses in Eusebius, PE 10.3.25 (= DK80B2) are divided into two texts each, a testimony about his person and another about the reception of his thought (the first, divided in P22 and R19a, while the second is separated into D7 and R2).

\section{o’rchaí}

no 23, May-Aug. 2018

Sergio

Javier

Barrionuevo,

'An overview of the Corpus Protagoreum: A Bibliographical Note on Laks and Most's Early Greek Philosophy.', p. 343-374 


\section{o’rchaí}

no 23, May-Aug. 2018

Sergio Javier

Barrionuevo, 'An overview of the Corpus Protagoreum: A Bibliographical Note on Laks and Most's Early Greek Philosophy.', p. 343-374

\subsection{THE NEW TEXTS}

This edition includes fifteen texts not included in Diels and Kranz's edition: two texts in $P$, four texts in $D$, and nine in $R$. The texts included in $P$ correspond to Plato, Protagoras 310a-b, 310e-311a (P10) , and Richter (1965: I, 108) (P24); the first was included as testimony of the arrival of Protagoras in Athens, and the second as iconographic testimony. While the four texts included in $D$ corresponds to P.Berol. Inv 9782, Col. 2.3-8 (D5c), Plato, Phaedrus 267bc (D22b), Protagoras 320c (D39), and 322d-323a (D41), the first text (D5c) had already been edited as a complement in Decleva Caizzi (1999 = CPF88 $1 \mathrm{~T})$ and is a passage in which the title of his treatise On Truth is complemented by Plato, Theaetetus 161 (D5a = DK B1), and Cratylus 391c (D5b = DK A24). The second (D22b) is included as a testimony to the Protagoras' orthoepeia ('correctness of language'). While texts D39 and D41 are included as references to the doctrine expressed by the "Protagoras' myth" included in Plato's Protagoras, the first (D39) is a testimony of his position regarding the fictional character of the opposition logos-muthos, and the second (D41) is an explanation of the Protagoras' myth. Finally, of the nine texts added in $R$, four refer to the Platonic reception of protagorean doctrines of "Man-Measure" in Theaetetus 152c-e (R6), 162c (R7b), 163e-164a (R8), 170a3-c5 (R9a), and in Laws 4.716c (R11); two to the Aristotelian reception in Metaphysics K6 1062b-13-19 (R14b), and I1 1053a31-b3 (R15), while Damascius, Treatise on the First Principle 126.2 (R26) refers to the Neoplatonic reception and Didymus the Blind, Commentary on the Psalms 34.17 (R27) to the patristic reception. The 
text R15, included in the Aristotelian reception, had previously been published by Untersteiner (1949) as $\mathrm{B}^{\star} 13 \mathrm{~b}$; R27 had already been defined as a new fragment by Gronewald (1968) and later included in Decleva Caizzi $(1999=$ CPF 88 3T $)$.

\subsection{EXCLUDED TEXTS}

Laks and Most's edition relocates some of the texts included by Diels and Kranz in their section on Protagoras (80). In this case, the passage of Plato (Hippias Major 282d-e = DK 80A9) is included as testimony about the person of Hippias (LM 36P4). While the passages of Aristophanes (Clouds 112-115 and 658$679=$ DK 80C2) included as "Imitation" (C) in Diels and Kranz are included in section 42 (“'Sophist' and 'Sophistic': Collective Representations and General Characterizations") as T19 a and c, respectively.

Likewise, the testimonies DK80A4 and A23, as well as the imitation $\mathrm{C} 1$, were partially included. First, the DK80A4 testimony was composed of two sources; Eusebius of Cesarea (Jerome's Chronicles) is included in LM 31P4 as a testimony to the chronology, while Apuleyus (Florida 18) is outside. Second, with regard to DK80A23, the passage of Diogenes of Oenoandus fr. 12 is included as R24, i.e. a reference to Protagoras' Doctrine and Refutations of it. Whereas the passages of Plato (Theaetetus 162d), Ciceron (On the Nature of Gods, 12.29 and 24.63), and Philodemus (On the Pietus XXI, 89), which in Diels-Kranz are part of A23, were excluded in this new edition. Finally, although the passage Plato's Protagoras 320c-322e, which reproduces the so-called "Protagoras' myth", is included as D40; the passage of Aristotle (Parts of

\section{o’rchaí}

nº 23, May-Aug. 2018

Sergio

Javier

Barrionuevo,

'An overview of the Corpus Protagoreum: A Bibliographical Note on Laks and Most's Early Greek Philosophy.', p. 343-374 


\section{o’rchaí}

no 23, May-Aug. 2018

Sergio Javier

Barrionuevo, 'An overview of the Corpus Protagoreum: A Bibliographical Note on Laks and Most's Early Greek Philosophy.', p. 343-374
Animals IV 10, 687a23), however, was excluded. The new edition also excludes some of the texts included by Diels and Kranz. The testimonies DK80A13 (Plato, Cratylus 385e), A18 (Tertullianus, On the Soul 15), and A22 (Plato, Protagoras 333d) were rejected as such by Laks and Most (2016).

\section{ENDING REMARKS}

Laks and Most's (2016a) new edition is not only a reordering of the texts collected by Diels and Kranz (1952) but also a reorganization of texts based on new criteria, allowing them to recover the importance of many fragments and testimonies from this new perspective. Many texts that received little attention from scholars due to the limitations imposed by the criteria of Diels and Kranz are revalued and placed in a central place. Such is the case, for example, of the testimonies conserved in the Athenian comedy ${ }^{7}$ or the reception of protagorean thought in antiquity. It also allows the evaluation of the texts from a new perspective, which does not stand on the discussion about whether to include them in the "fragment" category but rather highlight the ways in which they were read by tradition. Therefore, this new edition promises to renew studies on the early philosophers in general and on sophistry and Protagoras in particular. It proposes to both incorporate new texts and establish a new way of reading and thinking about ancient fragmentary texts.

\section{ENDNOTES}

1 Most of the twentieth-century translations of pre-Socratic texts use this edition as a basis (Garcia Bacca 1943, Freeman 1957, Giannantoni 1969, Eggers Lan 1978-80, Dumont 1988, Lami 1991), as well as some 
recent editions (Reale 2006, Graham 2010). Some of the editions of the sophists also followed the corpus established by Diels and Kranz (Piqué Angondans 1985, Sprague 2001), although many of them incorporate later contributions (Melero Bellido 2000, Solana Dueso 2013). Recently, Mauro Bonazzi, an Italian translator of the sophists, reproduced the text in full from Diels and Kranz (Bonazzi 2007). In his collaboration. the French translation (directed by J.-F. Pradeau) was reviewed and changes were made regarding Diels and Kranz (Bonazi 2009).

The additional passages included by Capizzi (1956) are: Aëtius IV, 9.1; Alex.Aphr. in Metaph. 155.34ss., 247.11-12, 273.29-32, 541.12-13; Ammon. in Cat. 114; Anonymus, Rh. 49.4-5; Arist. Metaph. IV.5, 1009b1-6, 1009a6-13, X.1, 1053a31-1053b3; Ascl. in Metaph. 155, 186, 188, 197; Ath. VIII, 354s; Cic. Acad. II, 46; Clem.Al. Strom.I.64; D.L. IX.8; E. Antiop.82.2; Elias in Cat.265; Epiph. A.H. III.16; Eus. PE X.14, XIV.2, 3, 17, 19.8, 20; Gal. [Ps.] Hist.Phil.3; Gell. NA V.10; Gell. NA V.3; Mch. in EN 146.47-50; Phlp. in De an. 8, 30-33; Pl. Rsp. 600c-d, Sph. 236d-239d, Tht. 164e-165a, 170a, 178b, 188d-189b; Plut. Adv.Colot. IV.1108f; Plut. Nicias 23; Quint. Inst. III.4; Simp. In De

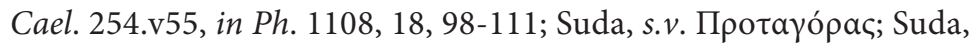

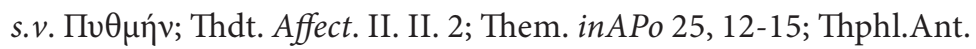
Autol. III.28.

3 This book is the result of his doctoral thesis entitled Of science, skepticism and sophistry: The pseudo-Hippocratic On the Art in its philosophical context supervised by L. Dean-Jones and R. Hankinson, evaluated by a jury composed by M. Gagarin, A. Mourelatos, and P. B. Woodruff at the University of Texas (Austin) in 2005.

4 This compilation should not have been very systematic, according to the judgment of Vitringa (1853: ix): "de systemate aliquo philosphae Protagorae ne cogitavit quidem".

For a comparative scheme, see the tables included at the end of this review (Appendix).

He dedicates all of section II of his Heraclitea to the reception of the thought of Heraclitus in antiquity and the middle ages. So far, four volumes have been published corresponding to the first part (Heraclitea II.A1-4); three more parts are pending (II.B-D).

Recently, along with Laks and Most's (2016a) publication, a selection and translation of the mockery of philosophers and sophists in the fragments of the Athenian comedy was published in Spanish, see Barrionuevo (2016).

\section{ỏrchaí}

no 23, May-Aug. 2018 


\section{o’rchaí}

no 23, May-Aug. 2018

Sergio

Javier

Barrionuevo, 'An overview of the Corpus Protagoreum: A Bibliographical Note on Laks and Most's Early Greek Philosophy.', p. 343-374

\section{BIBLIOGRAPHY}

BARRIONUEVO, S. (2016). Burlas a filósofos y sofistas en los fragmentos cómicos griegos. El Arco y la Lira. Tensiones y Debates 4, p. 105-117.

BONAZZI, M. (2007). I Sofisti. Milano, BUR.

BONAZZI, M. (2009). Protagoras d'Addère (environ 490-420 av. J.C.). In: PRADEAU, J.-F. (dir.). Les sophistes, vol. 2. Paris, Flammarion, p. 43-90.

CAPIZZI, A. (1955). Protagora, le testimonianze e i frammenti. Edizione reveduta e ampliata con uno studio su la vita, le opere, il pensiero e la fortuna. Florence, Sansoni.

CAVALLO, G. and CHARTIER, R., (eds.) (1997). Histoire de la lecture dans le monde occidental. Paris, Seuil.

DECLEVA CAIZZI, F. (1999). Protagoras. In: Corpus dei filosofi grecie e latini. Testi e lessico nei papiri di cultura greca e latina (CPF), Parte I. Autori Noti, Volumen $1^{\star * \star}[2]$ (Platonis testimonia - Zeno Tarsensis). Firenze, Leo Olschki, p. 663-676.

DIELS, H. (1903). Die Fragmente der Vorsokratiker, 2 vols. Berlin, Weidmannsche Buchhandlung.

DIELS, H.; KRANZ, W. (1952). Die Fragmente der Vorsokratiker, 3 vols. Berlin, Weidmannsche Verlagbuchhandlung.

DUMONT, J.-P. (1988). Les présocratiques. Paris, Gallimard.

EGGERS LAN, C. (1978-80). Los filósofos presocráti$\cos , 3$ vols. Madrid, Gredos. 
FREEMAN, K. (1957). Ancilla to the Pre-Socratic philosophers. Cambridge, Harvard University Press.

FREI, J. (1845). Quaestiones protagoreae. Bonn, Adolphus Marcus.

GARCÍA BACCA, J. D. (1943). Los presocráticos, 2 vols. México, El Colegio de México.

GEEL, J. (1823). Historia critica sophistarum qui socratis aeatate Athenis floruerunt. Lugdunum Batavorum [= Leiden], Societate Rheno-Trajectina.

GEIST, E. (1827). De Protagorae sophistae vita disquisitio. Gisensis [= Gießen], Program paedagogik.

GINNANTONI, A. (1969). I presocratici: testimonianze e frammenti, 2 vols. Bari, Laterza.

GRAHAM, D. W. (2010). The Texts of Early Greek Philosophy: The Complete Fragments and Selected Testimonies of the Major Presocratics. Cambridge, Cambridge University Press.

GRONEWALD, M. (1968). Ein neues ProtagorasFragment. ZPE 2, p. 1-2.

HERBST, L. F. (1832). Des Protagoras Leben und Sophistik aus den Quellen zusammengestellt. In: PETERSEN, Ch., ed. Philosophisch-historische Studien auf dem Akademischen Gymnasium in Hamburg. Hamburg, Perthes und Besser, p. 88-157.

LÁKS, A.; MOST, G. W. (2016a). Early Greek Philosophy, 9 vols. Cambridge, Harvard University Press.

LÁKS, A.; MOST, G. W. (2016b). Les débuts de la philosophie. Des premiers penseurs grecs à Socrate. Paris, Fayard.

\section{o’rchoí}

no 23, May-Aug. 2018

Sergio

Javier

Barrionuevo,

'An overview of the Corpus Protagoreum: A Bibliographical Note on Laks and Most's Early Greek Philosophy.', p. 343-374 


\section{ảrchaí}

no 23, May-Aug. 2018

\section{Sergio Javier}

Barrionuevo, 'An overview of the Corpus Protagoreum: A Bibliographical Note on Laks and Most's Early Greek Philosophy.', p. 343-374
LAMI, A. (1991). I presocratici: testimonianze e frammenti da Talete a Empedocle. Milano, BUR.

MELERO MELLIDO, A. (2000). Sofistas, Testimonios y fragmentos. Madrid, Gredos.

MOURAVIEV, S. (1999-2011). Heraclitea, 11 vols. published. Sankt Augustin, Akademia Verlag.

OSBORNE, C. (1987). Rethinking Early Greek Philosophy. Hippolytus of Rome and the Presocratics. Ithaca, Cornell University Press.

REALE, G. (2006). I presocratici. Testo greco a fronte. Milano, Bompiani.

RICHTER, G. M. A. (1965). The Portrait of the Greeks. London, The Phaidon Press.

SOLANA DUESO, J. (2013). Los sofistas, Testimonios y fragmentos. Madrid, Alianza.

SPRAGUE, R. K., ed. (2001). The Older Sophist. Indianapolis-Cambridge, Hackett Publishing Company.

SVENBRO, J. (1988). Phrasikleia: Anthropologie de la lecture en Grece ancienne. Paris, Éditions La Découverte.

VITRINGA, A. J. (1853). Disquisitio de Protagorae vita et Philosophia. Groningen, P. van Zweeden.

WEBER, O. (1850). Quaestiones Protagoreae. Dissertatio Inauguralis. Marburg, Elwerti Academicus.

WÖHRLE, G., ed. (2009-11). Die Milesier, 2 vols. Berlin \& New York, De Gruyter. 


\section{Appendix: Source's Tables}

Table 1. Sources (Major editions of twenty century)

\begin{tabular}{|c|c|c|c|c|}
\hline SOURCE & $\begin{array}{l}\text { DIELS- } \\
\text { KRANZ } \\
(1952)\end{array}$ & $\begin{array}{l}\text { UNTER- } \\
\text { STEINER } \\
(1949)\end{array}$ & $\begin{array}{l}\text { CAPIZZI } \\
(1956)\end{array}$ & $\begin{array}{l}\text { LAKS \& } \\
\text { MOST } \\
(2016)\end{array}$ \\
\hline Aëtius IV, 9, 1 & $70 \mathrm{~A} 22$ & --- & A18a & --- \\
\hline $\begin{array}{l}\text { Alex.Aphr. in Metaph. } \\
\text { 155, 34ss. }\end{array}$ & -- & -- & A11b & -- \\
\hline $\begin{array}{l}\text { Alex.Aphr. in Metaph. } \\
247,11-12\end{array}$ & --- & --- & A19a & -- \\
\hline $\begin{array}{l}\text { Alex.Aphr. in Metaph. } \\
247,11-12\end{array}$ & $-1-$ & --- & A19a & -- \\
\hline $\begin{array}{l}\text { Alex.Aphr. in Metaph. } \\
273,29-32\end{array}$ & -- & -- & A19a & -- \\
\hline $\begin{array}{l}\text { Alex.Aphr. in Metaph. } \\
541,12-13\end{array}$ & $-1-$ & --- & A17 & --1 \\
\hline Ammon. in Cat. 114 & --- & --- & $\mathrm{A} 19 \mathrm{~b}$ & --- \\
\hline $\begin{array}{l}\text { Ammon. Schol. Homer. } \\
\text { XXI, } 240 \text { (Grenfell- } \\
\text { Hunt Oxyrh. Pap. II, } \\
\text { p. 68) }\end{array}$ & $80 \mathrm{~A} 30$ & Ibidem & Ibidem & D32 \\
\hline Anecd.Gr. I, 171, 31-33 & $80 \mathrm{~B} 3$ & Ibidem & B4 & $\begin{array}{l}\text { D8, D11 } \\
\text { R23 }\end{array}$ \\
\hline Anonymus, $R h .49,4-5$ & $-1-$ & - - - & A21 & $-1-$ \\
\hline Apul. Flor. 18 & $80 \mathrm{~A} 4$ & Ibidem & Ibidem & - - \\
\hline Ar. Nu. 112-115 & $80 \mathrm{C} 2$ & Ibidem & Ibidem & 43T19a \\
\hline Ar. Nu. 658-679 & $80 C 3$ & Ibidem & Ibidem & $43 \mathrm{~T} 19 \mathrm{c}$ \\
\hline Ar. $N u .882-85$ & - - & - - & - - & $43 \mathrm{~T} 19 \mathrm{~b}$ \\
\hline $\begin{array}{l}\text { Arist. Metaph. II, 2, } \\
\text { 997b32-998a6 }\end{array}$ & $80 \mathrm{~B} 7$ & Ibidem & A11b & D33 \\
\hline $\begin{array}{l}\text { Arist. Metaph. IV, 4, } \\
\text { 1007b18-25 }\end{array}$ & $80 A 19$ & Ibidem & Ibidem & $\mathrm{R} 17$ \\
\hline $\begin{array}{l}\text { Arist. Metaph. IV, 5, } \\
\text { 1009a6-13 }\end{array}$ & --- & --- & A19a & --- \\
\hline $\begin{array}{l}\text { Arist. Metaph. IV, 5, } \\
\text { 1009b1-6 }\end{array}$ & --- & --- & A17 & -- \\
\hline $\begin{array}{l}\text { Arist. Metaph. IX, 3, } \\
\text { 1046b29-1047a7 }\end{array}$ & $80 \mathrm{~A} 17$ & Ibidem & Ibidem & R16 \\
\hline
\end{tabular}

\section{a’rchaí}

no 23, May-Aug. 2018

Sergio Javier

Barrionuevo, 'An overview of the Corpus Protagoreum: A Bibliographical Note on Laks and Most's Early Greek Philosophy.', p. 343-374 


\section{o’rchaí}

$\mathrm{n}^{\circ} 23$, May-Aug. 2018
Arist. Metaph. VI, 2, 1063a1-6

Arist. Metaph. X, 1, 1053a31-1053b3

Arist. Metaph. XI, 6, 1062b13-19

Arist. PA IV 10, $687 \mathrm{a} 23$

Arist. Po. 19, 1456b15- 80A29 Ibidem 17

Arist. Rh. II, 24, 1402 $23-27$

Arist. Rh. III, 5, 1407b7-8

Arist. 23

Ascl. in Metaph. 155

Ascl. in Metaph. 186

Ascl. in Metaph. 188

Ascl. in Metaph. 197

Ath. V 218B

Ath. VIII, 354s

Ath. XI, 505F-506A

Cic. Acad. II, 46

Cic. Acad. II, 18.56

Cic. Acad. II, 40.125

Cic. Brut. XII, 46

Cic. leg. I, XVI-XVII, 42-47

Cic. ND I, 12, 29

Cic. ND I, 24, 63

Cic. Orat. III, 32.128

Clem.Al. Strom. I, 64

Clem.Al. Strom. VI, 65

D. L. IX, 51

D.L. III, 37

D.L. III, 57
80A21 Ibidem

80A27 Ibidem

Ibidem

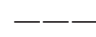

---

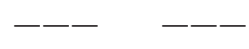

- -

80A1

$68 \mathrm{~A} 9$

$80 \mathrm{~A} 11$

- -

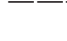

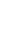

$80 \mathrm{~B} 6$

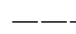

- -

Ibidem

- - -

Ibidem
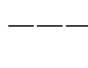

- - -

Ibidem

$80 \mathrm{~A} 23 \mathrm{a}$

80A23 Ibidem

80A23 Ibidem

84B3

$70 \mathrm{~A} 1$

$80 \mathrm{~A} 20$

80B4

$(=\mathrm{A} 1)$

80B5

80B5

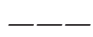

-一-

Ibidem

Ibidem

Ibidem
Ibidem

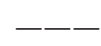

R14b

A13a R15

A19 R14a

Ibidem D25

Ibidem R18

Ibidem D23

Ibidem D24

A19

A19a

B2

A18

Ibidem

A30b

Ibidem

A19a

- - -

R109a

- - - R109b

A20 D18

Ibidem

Ibidem

-- -

A3b

Ibidem

Ibidem

D10

A20 R1a

A20 R1b 


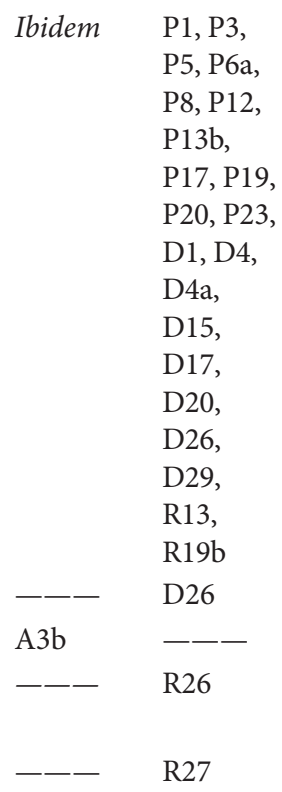

Didym. in Ps. 34, 17 (M. Gronewald, Tura Papyrus II, Columna 222, 15-29)

Diogen.Oenoand. fr. 12, cap. 2, 1 (16.II-III Smith)

E. Antiop. 82,2

E. Ba. 199 ss.

E. fr. 591 (Nauck)

Elias, in Cat. 265

Epiph. A.H. III, 16

Eup. fr. $157 \mathrm{~K}-\mathrm{A}$ (=

D.L. IX, 50.1; Eusth.

Comm. Hom. Od.

1547, 52 1.2-3)

Eup. fr. $158 \mathrm{~K}-\mathrm{A}$ (=

Plu. Quaest. conv. 699a;

Macr. Sat. VII, 15.22)

Eup. test. II K-A (=

80A11

Ibidem

80C4 $\quad$ Ibidem
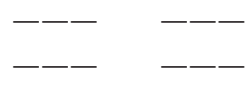

$$
\text { - }
$$

80A1, Ibidem

A11

$80 \mathrm{~A} 11$

Ibidem

Ath. V, 218C)

Eus. (= Hier.Chron. p.

113.20)

Eus. PE X, 14

Eus. PE XIV, 17

Eus. PE XIV, 19

Eus. PE XIV, 19,8
69A1

80A4 Ibidem
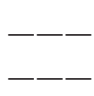

70B2

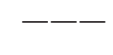

Ibidem

R24

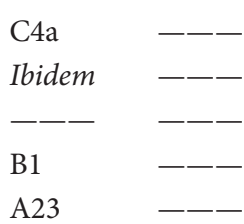

Ibidem 43T18b

Ibidem 43T18c

Ibidem 43T18a

Ibidem P4

A3b

A3b

B7

A18

\section{o’rchoí}

no 23, May-Aug. 2018

\section{Sergio}

Javier

Barrionuevo, 'An overview of the Corpus Protagoreum: A Bibliographical Note on Laks and Most's Early Greek Philosophy.', p. 343-374 


\section{o’rchaí}

$n^{\circ}$ 23, May-Aug. 2018
Eus. PE XIV, 2

Eus. PE XIV, 20

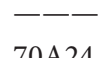

70A24
A18

A13b

$\mathrm{R} 12$

Eus. PE XIV, 3

Eus. PE XIV, 3, 7

Eust. 1547, 53

Gal. [Ps.] Hist.Phil. 3

Gell. NA V, 10

Gell. NA V, 3

Gnom. Vat. 743 (ed.

Stertertulianonbach,

n. 468)

GS sprüche(trad. Ryssel, p. 539, n. 32)

Herm. Irris. IX (D. 653)

Herm. (= $\Sigma$ in Pl. Phdr. 267c)

Hsch.Mil. Onomatol. (= $\Sigma$ in Pl. Rp. 600c)

Isoc. $\mathrm{X}, 2$

Lact. Inst. I, 2

Lact. Ir.D. 9

Max.Tyr. XVII, 5

Mch. in EN 146, 47-50

Min.Fel. Oct. 8

PBerol. inv. 9782, col. 2.3-8

Philostrat., VS, I, 10, 1-4

Phld. Piet. XXI, 89

Phld. Po.C fr. XI, p. 243

$\begin{array}{ll}--- & --- \\ \text { 80B4 } & \text { Ibidem } \\ \text { 80A11 } & \text { Ibidem } \\ --- & --- \\ --- & --- \\ --- & --- \\ \text { 80A25 } & \text { Ibidem }\end{array}$

80B12

80A16

Ibidem

Ibidem

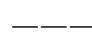

Ibidem

$80 \mathrm{~A} 3$

Ibidem
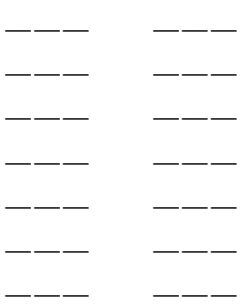

$80 \mathrm{~A} 2$

$80 \mathrm{~A} 23$

$80 \mathrm{~B} 7 \mathrm{a}$

[Na-

chtrag, vol. II, p.

425]

Phlp. in Cat. 81, 6-8

Phlp. in De an. 8,

30-33

Pl. Cra. 385e-f

Pl. Cra. 391b-c
A15

B7

A11a

A3b

A4

A3b

Ibidem

P18

Ibidem R30

Ibidem R28

- - D22b

Ibidem P16,

D16, D32

A8

A23

A23

A23

A6

A23

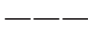

D5c

P7, P21,

R3, R25

D34

\section{4}


Pl. Crat. 400d

Pl. Crat. 429c-d

Pl. Euthd. 283e-284c

Pl. Euthd. 286b-c

Pl. Hp.Ma. 282d-e

Pl. Lg. IV 716c

Pl. Men. 91d

Pl. Men. 91e

Pl. Phdr. 266d

Pl. Prt. 310a-b, 31e$-311 a$

Pl. Prt. 316c5-317c5

Pl. Prt. 318a

Pl. Prt. 318d

Pl. Prt. 319a

Pl. Prt. 320c

Pl. Prt. 320c-322e

Pl. Prt. 320c-328c

Pl. Prt. 322d-323a

Pl. Prt. 324a-b

Pl. Prt. 326e-328b

Pl. Prt. 328b-c (cf. C1)

Pl. Prt. 329b

Pl. Prt. 333d-334c

Pl. Prt. 338e-339e

Pl. Prt. 348e

Pl. Rsp. 600c-d

Pl. Sph. 232b-e

Pl. Sph. 236d-239d

Pl. Tht. 151e-152e

Pl. Tht. 152c-e

Pl. Tht. 161c

Pl. Tht. $162 \mathrm{c}$

Pl. Tht. $163 \mathrm{e}-164 \mathrm{a}$

Pl. Tht. $164 \mathrm{e}-165 \mathrm{a}$

Pl. Tht. 170a

Pl. Tht. 170a3-c5

Pl. Tht. $178 \mathrm{~b}$

Pl. Tht. 188d-189b
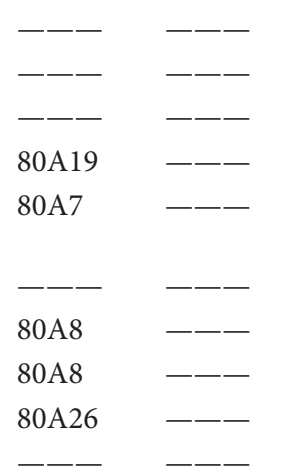

80 A5

80A5

80A5

80A5

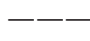

80C1

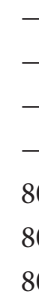

$-$

$$
\text { [33 }
$$$$
\kappa \tau \lambda \text {.] }
$$

$80 \mathrm{~A} 25$

80A5 Ibidem

Ibidem D31, D42

Ibidem D37,

P13a

A5

A20

D2

A19b

A13

- - -

Ibidem

- - - R7b

Ibidem

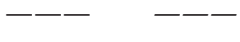

$-$

$$
\text { 80B }
$$$$
\text { 80B1 Ibidem }
$$

-- - - -

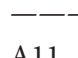

A11

A19a

- - -

R9a

A13

A19a

\section{o’rchaí}

$n^{\circ}$ 23, May-Aug. 2018

Sergio

Javier

Barrionuevo, 'An overview of the Corpus Protagoreum: A Bibliographical Note on Laks and Most's Early Greek Philosophy.', p. 343-374 


\section{o’rchaí}

no 23, May-Aug. 2018
Pl. Tht.162d

Pl. Tht.166d-167d

Pl. Tht.172a

Plu. Per. 36.5

Plut. Adv.Colot. IV, $1108 \mathrm{f}$

Plut. Nicias 23

Plut.[Ps.] Cons. ad

Apoll. 33, 118e (= Plut.

Moralia II, 10)

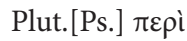

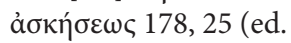

Lagarde)

Porph. 401F Smith (=

Eus. PE X 3, 25)

Quint. Inst. III, 1, 10

Quint. Inst. III, 4

Richter I, p. 108

S.E. M. IX, 55-57

S.E. $M$. VII, 389-90

S.E. $M$. VII, 60-64

S.E. P. I, 216-219

S.E., $M$. VIII, 65

Seneca Ep. 88, 43

Simp. In De Cael. 254, v55

Simp. in Ph. 1108, 18, 98-111

St.Byz. s.v. 'A $\delta \beta \eta \rho \alpha$

Stob. III (Flor.) 29, 80

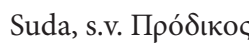

Suda, s.v. Протаүópas

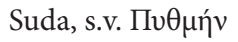

Tert. de An. XV, 6

Thdt. Affect. II, III, 2

Them. in APo 25,

12-15

Thphl.Ant. Autol. III,

28

$\begin{array}{llll}\text { 80A23 } & \text { Ibidem } & \text { Ibidem } & --- \\ \text { 80A21a } & \text { Ibidem } & \text { Ibidem } & \text { D38 } \\ --- & \text { A21a [adjunto] } & --- & --- \\ \text { 80A10 } & \text { Ibidem } & \text { Ibidem } & \text { D30 } \\ \text { 68B156 } & --- & \text { A15 } & \text { 27R89 } \\ & & & \\ \text { 59A18 } & - \text { - } & \text { A11a } & - \text { - } \\ \text { 80B9 } & \text { Ibidem } & \text { Ibidem } & \text { P11 }\end{array}$

B5

D13

Ibidem

B1

D7, R2

A4

D19

A29a

- - P24

Ibidem P22,

R19a

Ibidem R22

Ibidem D3

Ibidem R21

A14

Ibidem D27

A19a

A7a

Ibidem D28

A22 D12

A3a

A3a

A29a

80A18

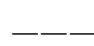

A

A23

A20a

A23 
TABle 2: Concordance (DK 80 = LM 31 [РROT.])

A. Diels and Kranz (1952) to Laks and Most (2016a)

A1: P1, P3, P5, P6A, P8, P12, P13b, P17, P19, P20, P23, D1, D4a, D15, D17, D20, D26, D29, R13, R19b, 43T18b [Dram.]

A2: P7, P21, R3, R25

A3: P6b, P13c, P16, D16

A4: P4

A5: P2a, P13a, D35, D36, D37, 42R11a [Soph.], R11B, R12

A6: P15

A7: D14

A8: P2b, P14

A9: 36P4 [Hippias]

A10: D30

A11: P9a, P9b, 43T18a [Dram.], T18b, T18c

A12: P22, R19a

A14: R21

A15: R22, R9b

A16: R28

Sergio Javier

Barrionuevo, 'An

overview of the

Corpus Protagoreum:

A Bibliographical

Note on Laks and

Most's Early Greek Philosophy.', p. 343-374

A17: R16

A19: R10, R14a, R17

A20: D27

A21: D28, R18

A21a: D38

A23: R24

A24: D5b, D21 


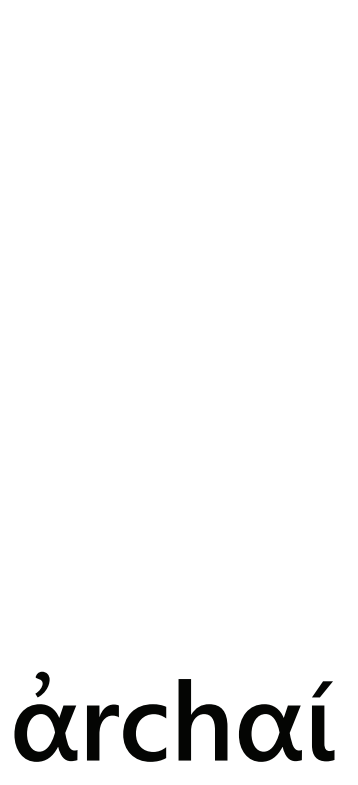

no 23, May-Aug. 2018

Sergio Javier
Barrionuevo, 'An
overview of the
Corpus Protagoreum:
A Bibliographical
Note on Laks and
Most's Early Greek
Philosophy.', p. 343-374

A26: D22a

A27: D23

A28: D24

A29: D25

A30: D32

B1: D3, D5a, D9, R4, R5, R7a, R20

B2: D7, R2

B3: D8, D11, R23, 43 T71 [Dram.]

B4: D4B, D10, R29

B5: R1a, R1b

B6: D18, D19

B6a: D26

B7: D33

B7a: D34

B8: D2

B9: P11

B10: D12

B11: D13

B12: R30

C1: D40

C2: T19a

C3: T19c

B. Laks and Most (2016a) to Diels and Kranz (1952)

P1: A1 
P2a: A5

P2b: A8

P3: A1

P4: A4

P5: A1

P6b: A3

P7: A2

P8: A1

P9a: A11

P9b: A11

P10: No in DK

P11: B9

P12: A1

P13a: A5

P13b: A1

P13C: A3

P14: A8

P15: A6

P16: A3

P17: A1

P18: A25

P19: A1

P20: A1

P21: A2

P22: $\mathrm{A} 12$

P23: A1

\section{árchoí}

$n^{\circ}$ 23, May-Aug. 2018

Sergio Javier
Barrionuevo, An
overview of the
Corpus Protagoreum:
A Bibliographical
Note on Laks and
Most's Early Greek
Philosophy.', p. 343-374


P24: No in DK

D1: A1

D2: B8

D3: B1

D4a: A1

D4b: B4

D5a: B1

D5b: A24

D5c: No in DK

\section{o’rchaí}

no 23, May-Aug. 2018

Sergio Javier
Barrionuevo, 'An
overview of the
Corpus Protagoreum:
A Bibliographical
Note on Laks and
Most's Early Greek
Philosophy., p. 343-374

D6: B3

D7: B2

D8: B3

D9: B1

D10: B4

D11: B3

D12: B10

D13: B11

D14: A7

D15: A1

D16: A3

D17: A1

D18: $B 6$

D19: B6

D20: A1

D21: A24

D22a: A26 
D22b: No in DK

D23: A27

D24: A28

D25: A29

D26: A1, B6a

D27: A20

D28: A21

D29: A1

D30: A10

D31: A25

D32: A30

D33: B7

D34: B7a

D35: A5

D36: A5

D37: A5

D38: A21a

D39: No in DK

D40: C1

D41: No in DK

D42: A25

R1a: B5

R1b: B5

R2: B2

R3: A2

R4: B1

\section{árchoí}

$n^{\circ}$ 23, May-Aug. 2018

Sergio Javier

Barrionuevo, 'An overview of the Corpus Protagoreum: A Bibliographical Note on Laks and Most's Early Greek Philosophy.', p. 343-374 
R5: B1

R6: No in DK

R7a: B1

R7b: No in DK

R8: No in DK

R9a: No in DK

R9b: A15

R10: A19

R11: No in DK

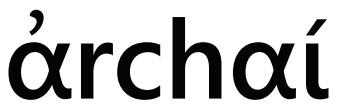

no 23, May-Aug. 2018

Sergio Javier

Barrionuevo, 'An

overview of the

Corpus Protagoreum:

A Bibliographical

Note on Laks and

Most's Early Greek

Philosophy.', p. 343-374
R12: 70A24

R13: A1

R14a: A19

R14b: No in DK

R15: ${ }^{\star} 13 \mathrm{~b}$ Untersteiner

R16: A17

R17: A19

R18: A21

R19a: A12

R19b: A1

R20: B1

R21: A14

R22: A15

R23: B3

R24: A23

R25: A2

R26: No in DK 
R27: No in DK

R28: A16

R29: B4

R30: B12

Submitted in February, 2016 and accepted for publication in April, 2017.

\section{o’rchoí}

$n^{\circ}$ 23, May-Aug. 2018 
